\title{
Isotopic evidence for dietary niche overlap between barking deer and four-horned antelope in Nepal
}

\author{
Krishna Prasad Pokharel ${ }^{1 *}$, Elizabeth Yohannes ${ }^{2}$, Ioanna Salvarina ${ }^{2}$ and IIse Storch ${ }^{1}$
}

\begin{abstract}
Background: Morphologically similar sympatric species may have a high degree of niche overlap. Barking deer Muntiacus vaginalis and four-horned antelope Tetracerus quadricornis are solitary ungulates of the Indian sub-continent. Limited information is available regarding their trophic ecology, particularly of the endemic four-horned antelope. We present stable carbon $\left(\delta^{13} \mathrm{C}\right)$, nitrogen $\left(\delta^{15} \mathrm{~N}\right)$, and sulphur $\left(\delta^{34} \mathrm{~S}\right)$ isotopic values, and nitrogen content $(\% \mathrm{~N})$ of faeces from barking deer and four-horned antelope living in lowland Nepal to assess trophic niche differentiation of these herbivores along the browser-grazer continuum. We also describe trophic differences between those two species in ecological niches and seasonal effects on their diets.

Results: We found that the barking deer and four-horned antelope consumed $C_{3}$ plant sources exclusively. The niche partitioning in their diet was reflected by $\delta^{34} S$ values. Some seasonal effects observed were: $\delta^{13} \mathrm{C}$ and $\delta^{15} \mathrm{~N}$ were significantly lower in the dry season diet of four-horned antelope than that of barking deer, while $\delta^{34} S$ values were significantly higher in the winter diet; monsoon diet was similar for both species. Faecal $N$ levels for barking deer and four-horned antelope were similar throughout all the seasons, indicating that both species adapted their feeding behaviour so as to maximize protein intake, in accordance with season and environment.

Conclusions: Barking deer and four-horned antelope both are browsers; their dietary sources overlapped during monsoon but differed during the dry season. Conservation actions focused on resource management during the dry season to reduce food scarcity and competition over limited resources is likely to be the most effective.
\end{abstract}

Keywords: Herbivores, Niche, Resource management, Resource partitioning, Seasonal diet, Stable isotopes

\section{Background}

The ecological niche of a species is a combination of the biotic and abiotic factors that affect the fitness (successful reproduction) of an individual or a population of that species [1,2]. According to niche theory, 'coexisting species should differ in their ecological requirements by at least some minimal amount to avoid competitive exclusion' ([3], pp. 2141). Niche partitioning among sympatric herbivores are largely related to the differences in body size $[4,5]$, and in part supported by predation [6]. Thus, morphologically similar herbivores may have high levels of ecological similarities that could result in competition when population density is high and resources are limited

\footnotetext{
* Correspondence: kp.pokharel@gmail.com

'Wildlife Ecology and Management, Faculty of Environment and Natural

Resources, University of Freiburg, Freiburg, Germany

Full list of author information is available at the end of the article
}

[6]. Hence, potentially competing sympatric species tend to partition their niches to avoid or lessen competition [3,6-8]. The mechanism allowing for niche partition occurs along at least three niche axes: spatial, trophic, and temporal [9]. The trophic niche is a major niche factor frequently partitioned $[6,10]$. Furthermore, trophic niche interactions between sympatric species can provide information on potential competition. However, Hubbell's neutral theory of biodiversity has challenged the niche theory [11]; he states that coexistence of species is possible without niche partitioning [12]. Furthermore, relationships between trophic niche overlap and competition are also an issue of controversy [13,14].

The trophic niche of ungulates is often classified along a browser/grazer continuum $[4,15,16]$. This rather coarse classification does not sufficiently reflect dietary differences of coexisting species $[9,17]$. Stable isotope analysis 
of animals' faeces has been widely used as a reliable source of information for dietary signatures over a range of temporal and spatial scales. Faeces retain isotopic dietary information of several hours to days, thus, isotope analysis of faeces presents an attractive non-invasive tool to assess mammals' short-term dietary patterns $[15,18,19]$. The stable carbon isotope $\left(\delta^{13} \mathrm{C}\right)$ in faeces reliably reflects the proportion of $\mathrm{C}_{3}$ plants (browse) to $\mathrm{C}_{4}$ plants (grass) ingested by the consumer [20-22]. The stable nitrogen isotope ratio $\left(\delta^{15} \mathrm{~N}\right)$ and faecal nitrogen content $(\% \mathrm{~N})$ both provide information on the trophic level of an organism, and indicate physiological stress and nitrogen uptake levels [23-25]. The stable sulphur isotope ratio $\left(\delta^{34} \mathrm{~S}\right)$ indicates the primary sulphur source in foods $[26,27]$. Hence, changes in $\delta^{13} C$, $\delta^{15} \mathrm{~N}$ and $\delta^{34} \mathrm{~S}$ values in the diet of herbivores may reflect a change in trophic niche and foraging habitat.

Most of the studies on trophic niche interactions among sympatric herbivores have been carried out in temperate zones [28-30] and tropical Africa [17,31,32]. However, few studies have focused on the diets of sympatric herbivores in subtropical Asia [33-35]. Moreover, those studies largely focused on sympatric ungulates with different body size. Therefore, barking deer Muntiacus vaginalis (Boddaert, 1785; BD hereafter) and four-horned antelope Tetracerus quadricornis (de Blainville, 1816; FHA hereafter), which are solitary herbivores with similar morphologies (shoulder height 55-65 cm, body mass $18-21 \mathrm{~kg}$; [36-38]) provide a good opportunity to study the trophic niche interactions between sympatric herbivores.

Overall, BD are described as exhibiting a wide variety of feeding habits that range from selective feeder $[39,40]$ to grazer [41] and mixed feeder [42], while FHA are defined as browsers and mixed feeders $[38,43,44]$. So far, most authors have reported qualitative descriptions, and quantitative assessment of the dietary sources of these two species is still lacking. Little is known about the dietary sources particularly that of FHA in Nepal, and whether there is a trophic niche partitioning between the two species. To fill these gaps, we assessed elemental stable isotope analysis $\left(\delta^{13} \mathrm{C}, \delta^{15} \mathrm{~N}, \delta^{34} \mathrm{~S}\right)$, and $\% \mathrm{~N}$ values from faeces to assess seasonal diet variation for sympatric BD and FHA in Bardia National Park, Nepal. Based on predictions from niche theory that 'coexisting species should differ in their ecological requirements by at least some minimal amount to avoid competitive exclusion' [3], we discuss the partitioning of dietary sources in terms of stable isotopes of these sympatric species. We expected to find the most pronounced differences in dietary sources and faecal isotopic values in seasons with limited food abundance.

\section{Results and discussion}

\section{Faecal stable isotopes and dietary sources}

According to the MANOVA, stable isotopes of faeces of the BD and FHA did not differ in terms of $\delta^{13} \mathrm{C}, \delta^{15} \mathrm{~N}$, $\delta^{34} \mathrm{~S}$ and \% $\mathrm{N}$ values (Pillai's Trace: $\mathrm{F}_{4,47}=1.546, p=0.204$ ), and sampling sites had no effect on diets of the two species (Pillai's Trace: $\mathrm{F}_{4,47}=1.862, p=0.133$ ). Furthermore, there was no effect of combined interactions between species and sampling sites (species $\times$ sampling sites) (MANOVA; Pillai's Trace: $\left.\mathrm{F}_{8,100}=1.38, p=0.22\right)$. However, there was a seasonal effect (Pillai's Trace: $\mathrm{F}_{4,47}=10.040, p<0.01$ ) as well as combined effect of interactions between species and seasons (species $\times$ seasons) (MANOVA; Pillai's Trace: $\mathrm{F}_{8,100}=2.61$, $p=0.012$ ). One-way ANOVA also revealed that stable isotopes of BD and FHA were similar in terms of $\delta^{13} \mathrm{C}$, $\delta^{15} \mathrm{~N}$ and $\% \mathrm{~N}$ values (Additional file 1). However, $\delta^{34} \mathrm{~S}$ values were higher for FHA faeces than for BD faeces $(\mathrm{F}=4.60, p=0.04)$.

Faecal $\delta^{13} \mathrm{C}$ values for BD $(-29.3 \pm 1.2)$ and FHA $(-29.7 \pm 1.4)$ were similar. Most published studies used stable $\mathrm{C}$ signatures of plant species from the study site to obtain the proportion of $\mathrm{C}_{3} / \mathrm{C}_{4}$ composition from faeces of study animal $[15,18,31]$. Here, we used the global stable $\mathrm{C}$ signatures for plants to compare our findings. We assumed that stable $\mathrm{C}$ signatures for the plants in Bardia National Park are similar to the range of stable $\mathrm{C}$ signatures for global $C_{3} / C_{4}$ plants, i.e., $\delta^{13} \mathrm{C}$ values ranged from -22 to $-37 \%$ with a mean of $-27 \%$ for $C_{3}$ plants, while $\mathrm{C}_{4}$ plants ranged from $-9 \%$ to $-15 \%$ with a mean of $-12.5 \%$ o $[45,46]$. Despite the fact that the majority of grass species available to herbivores in the study area are $C_{4}$ plants [47-50], faecal $\delta^{13} \mathrm{C}$ values from our study confirmed that the bulk of the BD and FHA diets consisted of $\mathrm{C}_{3}$ plants. Hence, our study confirmed that both species are browsers and their diet is composed of $\mathrm{C}_{3}$ plants with consistent nitrogen $\left(\delta^{15} \mathrm{~N}\right.$ and \%N) levels. Furthermore, similar $\delta^{13} \mathrm{C}$ values (Figure 1) for the study species indicated their dietary niches completely overlapped along the coarse level of the browser-grazer continuum.

If resources are not limiting population growth, coexistence of several species and the degree to which they overlap in their resource use are not a measure of competition, but are actually indicators of their similarities to one another [51]. Hence, completely overlapping preferences for browsing $\mathrm{C}_{3}$ plants over grazing $\mathrm{C}_{4}$ grasses signifies the similarities in feeding behaviour of these ungulates in lowland Nepal. Our findings that FHA are browsers are compatible with the findings of Sharma et al. [35] and Solanki \& Naik [40]. In an experiment in India, though the grass density was higher in experimental plots, Solanki \& Naik [43] found that FHA diets contained only about $9.41 \%$ grass. Similarly, Sharma et al. [38] also confirmed the preference of this species for browsing over grazing in their cafeteria experiment. Furthermore, our findings of $\mathrm{BD}$ as browsers are compatible with the findings of Barrette [39] in Sri-Lanka and Teng et al. [52] in Hainan Island, China. These authors mentioned this species as a browser with preference for forbs, fruits and 

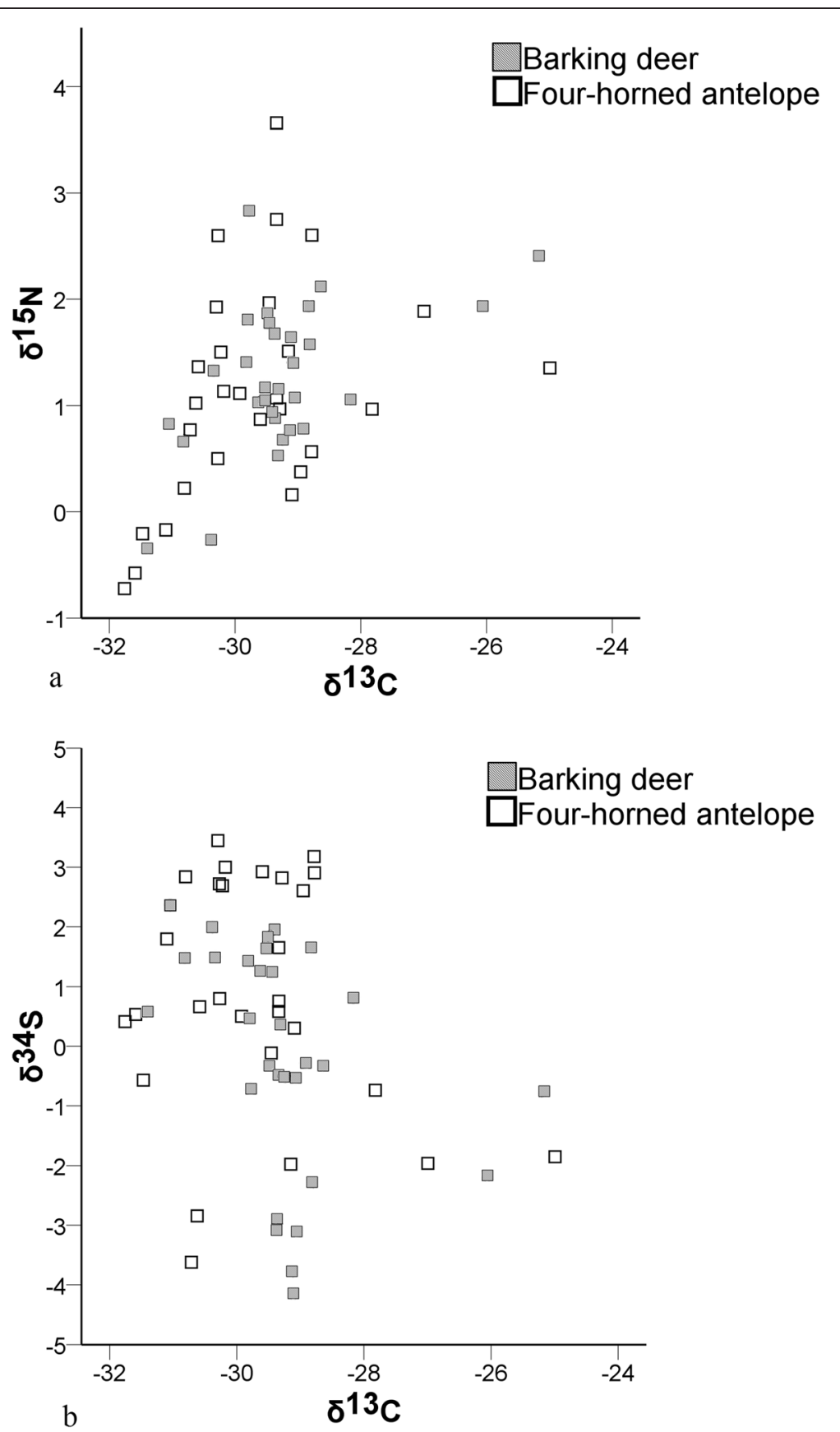

Figure 1 Scatter plots of stable isotopes of faeces of barking deer $(n=30)$ and four-horned antelope $(n=28)$. (a) $\delta^{13} \mathrm{C}$ and $\delta^{15} \mathrm{~N}$ signatures and (b) $\delta^{13} \mathrm{C}$ and $\delta^{34} \mathrm{~S}$ signatures.

young shoots rather than grass. But our findings contradict the findings of Yonzon [41], who mentioned BD as grazers in Chitwan National Park, Nepal and of Nagarkoti and Thapa [42] as a mixed feeder in the mid-hill region of Nepal. Such a difference in diet of the BD might be because of their higher adaptability to different habitat conditions. $\mathrm{BD}$ are widely distributed from south Asia to south-east Asia and from lowland to the high mountains [53], whereas the FHA is an endemic species with a narrow range of distribution only in the lowlands of the Indian subcontinent $[38,54]$. Moreover, BD use a variety of habitats, from dense forest in south-Asia $[39,55]$ to scrub grassland and thorny shrub land in Hainan Island, China [52], whereas FHA inhabit relatively open and dry forest in hilly terrain $[38,56]$. BD exhibit no seasonal home range [37]. Therefore, unlike FHA, it appears that BD have a greater adaptability to the habitat conditions and resource availability [57], leading to a wider range of feeding habits. 
Another important finding of this study, which cannot be covered by microscopic techniques of dietary analysis [58] alone, is higher faecal $\delta^{34} \mathrm{~S}$ values for FHA than for BD. Such differences in $\delta^{34} \mathrm{~S}$ values are perhaps due to the different foraging habitats of these animals because $\delta^{34} \mathrm{~S}$ values of plants are regulated by the $\delta^{34} \mathrm{~S}$ values of underlying local bedrock and microbial activities in soils $[59,60]$. Furthermore, in comparison to BD, FHA were more frequently encountered at mineral lick sites in Babai valley (personal observation). Perhaps the BD and FHA have differential preferences for the minerals that also contribute to the high variability in faecal $\delta^{34} \mathrm{~S}$ values.

\section{Intraspecific variation in seasonal diets}

Our analyses revealed that there was no significant seasonal effect on faecal stable isotopes of BD (MANOVA;
Pillai's Trace: $\left.\mathrm{F}_{8,50}=1.926, p=0.077\right)$. However, there was a significant seasonal effect on FHA isotope values (MANOVA; Pillai's Trace: $\mathrm{F}_{8,46}=3.528, p=0.003$ ). Oneway ANOVA revealed the difference in faecal $\delta^{13} \mathrm{C}$ : $\mathrm{F}_{2,25}=4.52, p=0.021, \mathrm{R}^{2}=0.27 ; \delta^{15} \mathrm{~N}: \mathrm{F}_{2,25}=4.29, p=$ $0.025, R^{2}=0.26$; and $\delta^{34} \mathrm{~S}: \mathrm{F}_{2,25}=4.35, p=0.024, \mathrm{R}^{2}=0.26$ (Figure 2, Additional file 1). Post-hoc analysis of FHA isotope values indicated that mean isotope values obtained during the dry season were significantly lower than that of the monsoon season for $\delta^{13} \mathrm{C}(p=0.019)$, $\delta^{15} \mathrm{~N}(p=0.036)$, and $\delta^{34} \mathrm{~S}(p=0.025)$. Winter season isotope values of the FHA were similar to values obtained during the dry $\left(\delta^{13} \mathrm{C}: p=0.145, \delta^{15} \mathrm{~N}: p=0.067\right.$, and $\left.\delta^{34} \mathrm{~S}: p=0.100\right)$ and monsoon $\left(\delta^{13} \mathrm{C}: p=0.690\right.$, $\delta^{15} \mathrm{~N}: p=0.980$, and $\delta^{34} \mathrm{~S}: p=0.860$ ) seasons (Figure 2). Results of the ANOVA showed no significant season

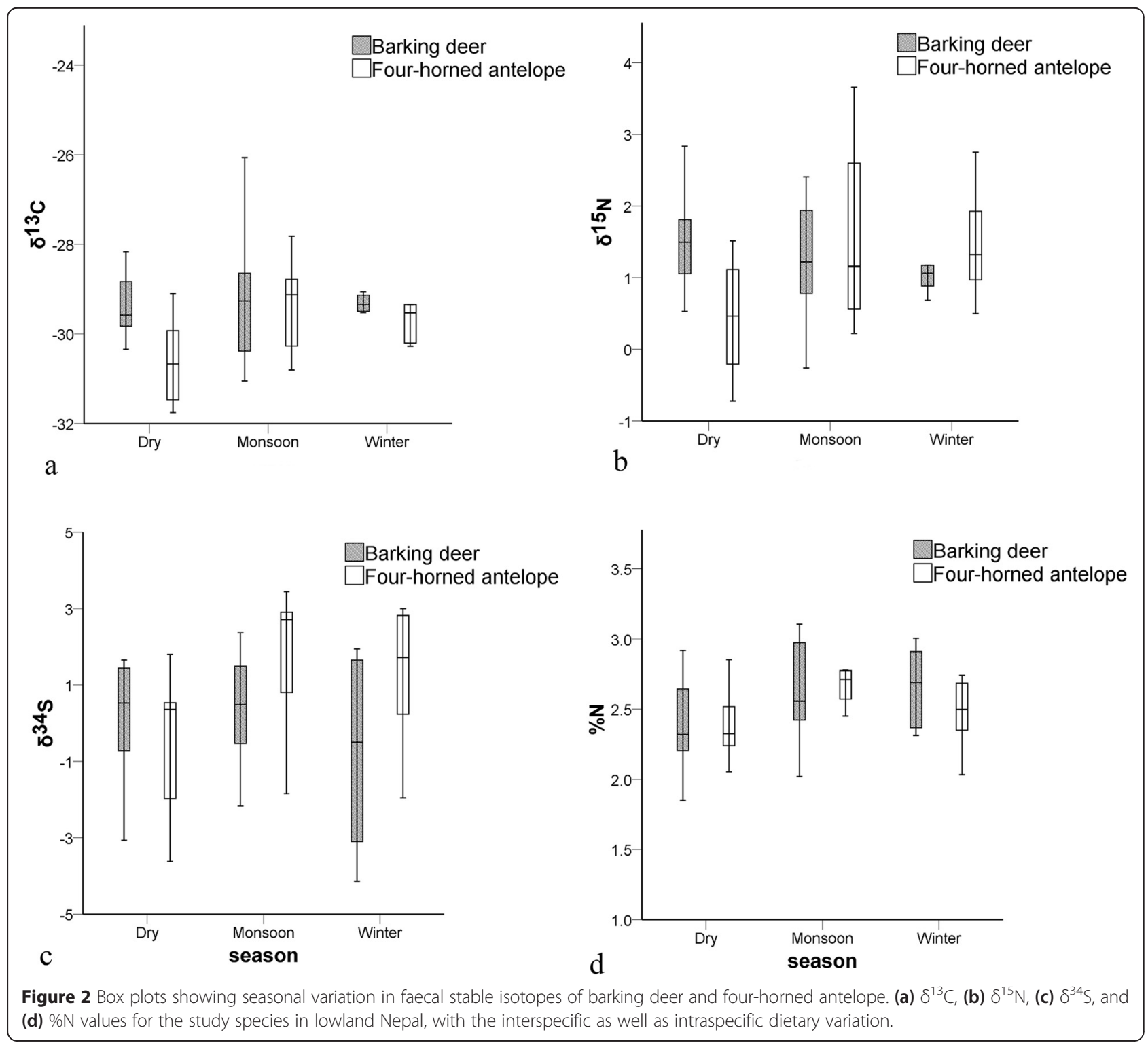


effect on BD or FHA faecal \%N (BD: $\mathrm{F}_{2,27}=2.51, p=$ $0.100, \mathrm{R}^{2}=0.16$; FHA: $\mathrm{F}_{2,25}=1.43, p=0.250, \mathrm{R}^{2}=0.10$ ) (Figure 2).

Stable isotope ratios differed significantly for FHA throughout the seasons but were consistent for BD (Figure 2). The main habitat of $\mathrm{BD}$, i.e., the riverine forest and Sal forests of Terai, is less susceptible to wildfire and water scarcity than the preferred habitat of FHA, i.e., hill sal forest and deciduous hill forest. Since water stress and forest fires affect the physiology of plants, and hence, the stable isotopes of the vegetation community [61-63], feeding on the same plant species from the same habitat types with consistent plant $\delta^{13} \mathrm{C}$ and $\delta^{15} \mathrm{~N}$ signatures is possible for $\mathrm{BD}$ but not for FHA. Furthermore, due to limited resources, FHA might have changed their feeding strategies by 1) shifting their diet to other parts of the same plant species that either remain unaffected by fire or are still edible after fire, e.g., bark; and/or 2) expanding their home range to another forest type to fulfil their energy requirements, foraging for the same plant species. Such a shift in diet without compromising diet quality might have led to the seasonal variation in $\delta^{13} \mathrm{C}, \delta^{15} \mathrm{~N}$ and $\delta^{34} \mathrm{~S}$ values for FHA.

\section{Interspecific variation in seasonal diets}

From the comparison of faecal stable isotope ratios between different seasons, we found that $\delta^{13} \mathrm{C}(\mathrm{F}=6.238$, $p=0.022)$ and $\delta^{15} \mathrm{~N}(\mathrm{~F}=6.478, p=0.020)$ values were significantly higher in the dry season diet of $\mathrm{BD}$ than that of FHA; $\delta^{34} \mathrm{~S}$ values $(\mathrm{F}=5.188, p=0.037)$ were significantly lower in the winter diet of $\mathrm{BD}$ than that of FHA, whereas isotope signatures were similar in the monsoon diets of both species. Diet quality in terms of $\% \mathrm{~N}$ was consistent throughout the seasons (Additional file 1 and Figure 2).

Faecal stable isotope ratios confirmed the seasonal niche portioning between $\mathrm{BD}$ and FHA for the dry season along the $\delta^{13} \mathrm{C}$ and $\delta^{15} \mathrm{~N}$ axis and along $\delta^{34} \mathrm{~S}$ axis for the winter season, but faecal stable isotope ratios were consistent for the monsoon season (Additional file 1 and Figure 2). These differences may correspond to the plant available moisture and availability of resources because plant available moisture, which affects $\delta^{13} \mathrm{C}$ as well as $\delta^{15} \mathrm{~N}$ values of plants [60], varies in different habitats even within the same season, leading to the different isotopic signatures for the same plant species. Furthermore, the monsoon season is the resource-rich period, with ample water resources and soft ground vegetation; but with the onset of winter, air moisture levels decrease and seasonal streams dry up. Dry season forest fires further increase resource scarcity. Furthermore, the quality of available diet in the dry season is poor [64] because most plants in lowland Nepal start to sprout with the pre-monsoon rains at the end of the dry season $[65,66]$.

In a study that applied faecal pellet belt transect surveys during the dry season in the same study site, Pokharel et al. [57] found strong evidence that FHA preferred hill sal forest and deciduous hill forest at higher elevations, whereas BD preferred riverine and sal forest at lower elevations. This is complementary to our faecal isotopic data obtained from the dry season for the two ungulates. Therefore, we suggest that the diets of $\mathrm{BD}$ and FHA are likely to be composed of different plant species. However, it is yet to be explored if the plants were the same species but of different habitat origin. Despite the interspecific variations in faecal $\delta^{13} \mathrm{C}, \delta^{15} \mathrm{~N}$, and $\delta^{34} \mathrm{~S}$ values for different seasons, the diet quality in terms of $\% \mathrm{~N}$ was consistent for both species (Additional file 1 and Figure 2). This indicates that BD and FHA are both capable of partitioning the resources under resourcelimited conditions and fulfilling their energy requirements without compromising diet quality. Our study furthermore supports theoretical expectations that sympatric animals should reduce competition by filling different trophic niches, that diet overlap should be greater among similar sized animals, and that diet overlap should decrease with decreasing food resources [30]. Similar to the findings of Dunbar [67] on high altitude herbivores in Ethiopia, and Prins et al. [68] on bovid species in southern Mozambique, our results support the hypothesis that dietary overlap decreases during the dry season when available food is in short supply. Hence, our prediction that BD and FHA depend on different dietary sources is partially supported. According to our expectations, we found more pronounced differences in dietary sources (as reflected by faecal isotopic values) during seasons when resources were limited. Indeed, an earlier study by Pokharel et al. [57] emphasized that differential resource use on hill sal and deciduous hill forest by FHA, particularly during the dry season, facilitated the niche differentiation that allowed species to co-exist. We hypothesize for future investigations that FHA use different habitats in different seasons and migrate seasonally at the local level, while BD do not.

\section{Conclusion}

Barking deer and four-horned antelope diet is composed of $\mathrm{C}_{3}$ plants, hence they are browsers. They have overlapping trophic niches in browser/grazer continuum relative to $\delta^{13} \mathrm{C}$, but have partitioned their trophic niche along the $\delta^{34} \mathrm{~S}$ axis. On a seasonal scale, we found completely overlapped trophic niches during monsoon season, but the degree of resource partitioning increased during winter and peaked during the dry season. Intraspecific seasonal diet was consistent for barking deer throughout the seasons, but varied for four-horned antelope. Such seasonal variability and resource partitioning, explained by faecal $\delta^{13} \mathrm{C}$, 
$\delta^{15} \mathrm{~N}$ and $\delta^{34} \mathrm{~S}$ values, was possible mainly because of the dietary shift of four-horned antelope. We hypothesize for future research that four-horned antelope is a weaker competitor and exhibit seasonal migration at the local level to solve the seasonal variability problem. In Bardia National Park and other parts of the lowland Nepal, focusing on dry season resource management to reduce the potential competition for limited resources is likely to be most successful, particularly for four-horned antelope.

\section{Methods}

\section{Study area}

We conducted this study in Babai valley in the southeastern part of Bardia National Park ( $28^{\circ} 23^{\prime} 0^{\prime \prime} \mathrm{N}, 81^{\circ} 30^{\prime}$ $0 " \mathrm{E})$ in Nepal. The park is located in the Terai, the lowlands near the Indian border $390 \mathrm{~km}$ west of Kathmandu
(Figure 3). It is the largest national park in the Terai covering an area of $968 \mathrm{~km}^{2}$ (www.dnpwc.gov.np assessed on 19 March 2014). The park has a subtropical monsoonal climate with three distinct seasons: monsoon (June to September), winter (October to February) and dry (March to May) seasons. Monthly mean temperature of the area ranges from a minimum of $10^{\circ} \mathrm{C}$ in January to a maximum of $45^{\circ} \mathrm{C}$ in June. Most of the rainfall occurs during the monsoon season (1560-2230 mm) from June to September (Department of Hydrology and Meteorology, Nepal: 2004 to 2009 unpublished data). The vegetation within the study area is sub-tropical, consisting of a mosaic of floodplain communities with riverine forest and climax sal Shorea robusta forest with patches of grassland (locally known as phanta). Tree species composing the upper canopy include Shorea robusta, Terminalia tomentosa,

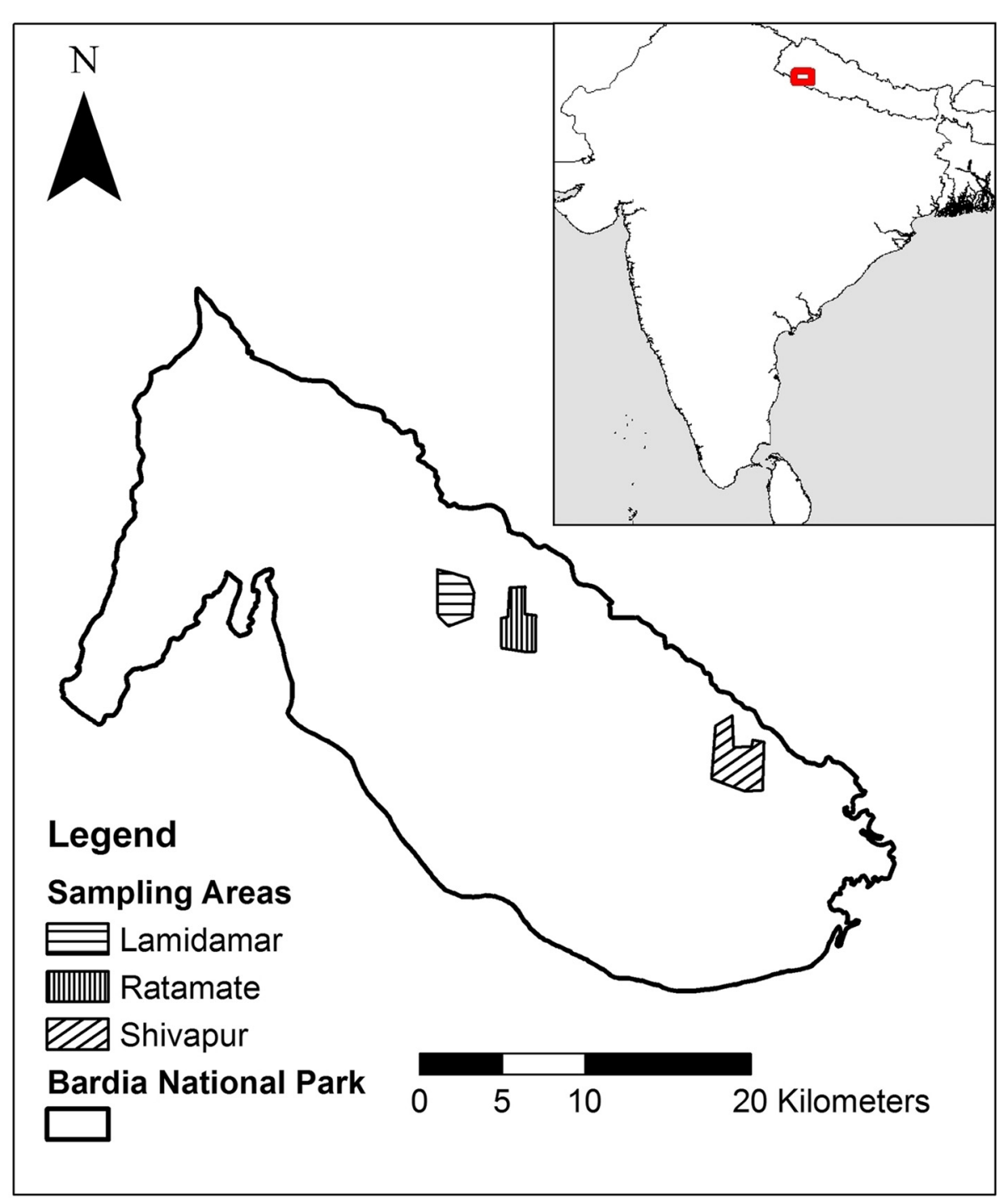

Figure 3 Survey areas within the Babai valley, Bardia National Park, Nepal. Their delineation encompasses the outermost sampling points. 
Mallotus philippensis, Acacia catechu, Dalbergia sissoo, Schleicheria trijuga, Pinus roxburghii, Buchanania latifolia, and Bombax ceiba while forest understory and grassland are dominated by grass species such as Saccharum spontaneum, S. ravennae, Vitiveria zizanoides, Imperata cylindrica, Cynodon dactylon, Erianthus ravennae, Eulaliopsis binata and Desmostachia bipinnata [33,69]. Most of the tree and shrub species found in the area are $C_{3}$ while the grass species are $C_{4}$ plants [47-50].

\section{Sample collection and stable isotope analysis}

Fresh faecal samples were collected from three different parts [i.e., Lamidamar, Ratamate (monsoon samples) and Shivapur (ca. 250-800 m a.s.l.) of the study area (Figure 3)]. Faecal samples were identified as 'fresh' if they were less than two days old, which was visually assessed based on the colour, texture and smell. We considered only those faecal pellets for collection, which were not contaminated by fungi, soil and insects. At least 18 samples were collected, and each sample was from a different dung pile of each species for each season (Additional file 2). Samples were first air-dried in the field, and then oven dried at $60^{\circ} \mathrm{C}$ for 24 hrs in the lab, thereafter mill-grounded through a $1 \mathrm{~mm}$ sieve into a homogenous powder.

Approximately $1.55 \mathrm{mg}$ of sample was weighed in a small tin cup using a micro-analytical balance. Samples were combusted using the vario Micro cube elemental analyzer (Elementar, Analysensysteme $\mathrm{GmbH}$, Germany) and the resultant $\mathrm{CO}_{2}, \mathrm{~N}_{2}$ and $\mathrm{SO}_{2}$ gases were introduced into a Micromass Isoprime isotope ratio mass spectrometer (Isoprime Ltd., Cheadle Hulme, UK) via a continuous flow-through inlet system. Sample ${ }^{13} \mathrm{C} /{ }^{12} \mathrm{C},{ }^{15} \mathrm{~N} /{ }^{14} \mathrm{~N}$ and ${ }^{34} \mathrm{~S} /{ }^{32} \mathrm{~S}$ ratios are expressed in the delta $\left(\delta^{13} \mathrm{C}, \delta^{15} \mathrm{~N}\right.$ and $\left.\delta^{34} \mathrm{~S}\right)$ notation in parts per million (\%o). Those values are relative to the following standards: the Vienna Pee Dee Belemnite (VPDB) for carbon, atmospheric $\mathrm{N}_{2}$ for nitrogen, and sulphanilamide-calibrated and traceable to NBS-127 (barium sulphate, $\delta^{34} \mathrm{~S}=+20.3 \%$ ) for sulphur. We obtained stable isotope ratios by using the equation:

$$
\delta X=\left[\left(\frac{R_{\text {sample }}}{R_{\text {standard }}}-1\right)\right] \times 1000
$$

where $X$ is ${ }^{13} \mathrm{C}$ or ${ }^{15} \mathrm{~N}$ or ${ }^{34} \mathrm{~S}$ and $R$ is ${ }^{13} \mathrm{C} /{ }^{12} \mathrm{C}$ or ${ }^{15} \mathrm{~N} /{ }^{14} \mathrm{~N}$ or ${ }^{34} \mathrm{~S} /{ }^{33} \mathrm{~S}$. Internal laboratory standards indicate that our measurement errors (SD) were $\pm 0.15 \%, 0.05 \%$ and $0.05 \%$ for $\delta^{15} \mathrm{~N}, \delta^{13} \mathrm{C}$, and $\delta^{34} \mathrm{~S}$, respectively.

\section{Statistical analysis}

For each species and element tested separately, q-q plots showed that variables were normally distributed. A Multivariate Analysis of Variance (MANOVA) [70] was applied where $\delta^{13} \mathrm{C}, \delta^{15} \mathrm{~N}, \delta^{34} \mathrm{~S}$, and $\% \mathrm{~N}$ were used as dependent variables; and species, sampling sites and seasons as main
Table 1 MANOVA (Pilli-test) results for stable isotopes of faeces of barking deer and four-horned antelope

\begin{tabular}{llll}
\hline Variables & df & $\mathbf{F}$ & $\boldsymbol{p}$ \\
\hline Area & 2 & 0.474 & 0.872 \\
Species $\times$ Area & 2 & 1.353 & 0.227 \\
Species & 1 & 1.475 & 0.224 \\
Season & 2 & 3.704 & 0.001 \\
Species $\times$ Season & 2 & 2.611 & 0.012 \\
\hline
\end{tabular}

Statistics include the degrees of freedom (df), F-ratio (F) and their significance level $(p)$ to show the variations in a combination of stable isotopes of faeces $\left(\delta^{13} \mathrm{C}, \delta^{15} \mathrm{~N}\right.$, and $\delta^{34} \mathrm{~S}$ signatures, and $\left.\% \mathrm{~N}\right)$ of the study species for study sites (area), season and their combinations.

effects. Only seasons and interaction between species and season (species $\times$ seasons) had a significant effect on dependent variables (Table 1). Therefore, we decided to omit the main effect variable 'sampling sites' from further analysis. After the MANOVA was conducted with season as a main effect variable, an one-way analysis of variance (ANOVA) followed by a Tukey's HSD post-hoc test [70] was performed for each dependent variable to detect differences between seasons for individual species (intra-specific seasonal variation). Seasons were analysed separately with species as a main effect variable for interspecific seasonal variation. We used IBM SPSS statistics version 20 (IBM corporation 2011, Armonk, NY, USA) for all statistical analysis and developing graphs.

\section{Additional files}

Additional file 1: Results from an ANOVA for stable isotopes of faeces of barking deer and four-horned antelope. Statistics include degrees of freedom (df), mean \pm standard deviation (SD), F-ratio (F), their significance level $(p)$ and variances explained $\left(R^{2}\right)$ to show the

interspecific variations in diets of the study species for dry, monsoon and winter seasons.

Additional file 2: Season, sites and dates of faecal sample collection of barking deer and four-horned antelope.

\section{Abbreviations}

BD: Barking deer; FHA: Four-horned antelope; MANOVA: Multivariate analysis of variance; ANOVA: Analysis of variance.

\section{Competing interests}

The authors declare that they have no competing interests.

\section{Authors' contributions}

KPP: data collection, lab work, data analysis and manuscript preparation; EY: lab work supervision, data analysis and manuscript preparation; loS: lab work, manuscript preparation; IS: research design and supervision, manuscript preparation. All authors read and approved the final manuscript.

\section{Acknowledgement}

We are thankful to the Department of National Parks and Wildlife Conservation (DNPWC) for research permits, and the Bardia National Park and National Trust for Nature Conservation (NTNC) for their logistical support. Field work would not have been possible without the invaluable help of Firulal Chaudhary, Ramraja, Bintiram, Tirtha, Ramesh Chaudhary and Indra Jaisi. Thanks are also due to Karl-Otto Rothhaupt for providing lab 
facilities, Saskia Rehse for assisting in the lab, and John A Bissonette and Jessica Schnell for manuscript language editing. KPP received funding for the lab works from Elisabeth-Frickenhaus Foundation and was supported by a PhD scholarship from state graduate funding (LGFG) through the International Graduate Academy (IGA) of the University of Freiburg. loS is a member of the International Max Planck Research School for Organismal Biology (IMPRS). The article processing charge was funded by the German Research Foundation (DFG) and the Albert Ludwigs University Freiburg in the funding programme Open Access Publishing. The funders had no role in study design, data collection and analysis, decision to publish, or preparation of the manuscript.

\section{Author details}

${ }^{1}$ Wildlife Ecology and Management, Faculty of Environment and Natural Resources, University of Freiburg, Freiburg, Germany. ${ }^{2}$ Limnological Institute, University of Konstanz, Konstanz, Germany.

\section{Received: 10 September 2014 Accepted: 29 April 2015 Published online: 06 May 2015}

\section{References}

1. Hutchinson GE. Concluding Remarks. In: Warren K, editor. Cold Spring Harbor Symposia on Quantitative Biology. Vol. 22. Cold Spring Harbor, NY: Cold Spring Harbor Laboratory Press; 1957. p. 415-27.

2. Holt RD. Bringing the Hutchinsonian niche into the 21st century: ecological and evolutionary perspectives. Proc Natl Acad Sci U S A. 2009;106:19659-65.

3. Pianka ER. Niche overlap and diffuse competition. Proc Natl Acad Sci U S A. 1974;71:2141-5

4. Jarman PJ. The social organisation of antelope in relation to their ecology. Behaviour. 1974;48:215-67.

5. Van Soest PJ. Allometry and ecology of feeding behavior and digestive capacity in herbivores: a review. Zoo Biol. 1996;15:455-79.

6. Schoener TW. Resource partitioning in ecological communities. Science. 1974;185:27-39.

7. MacArthur R, Levins R. The limiting similarity, convergence, and divergence of coexisting species. Am Nat. 1967;101:377-85.

8. Chillo V, Rodríguez D, Ojeda RA. Niche partitioning and coexistence between two mammalian herbivores in the Dry Chaco of Argentina. Acta Oecol. 2010;36:611-6.

9. Stewart KM, Bowyer RT, Kie JG, Dick BL, Ben-David M. Niche partitioning among mule deer, elk, and cattle: Do stable isotopes reflect dietary niche? Ecoscience. 2003;10:297-302.

10. MacArthur RH. Population ecology of some warblers of northeastern coniferous forests. Ecology. 1958;39:599-619.

11. Alonso D, Etienne RS, McKane AJ. The merits of neutral theory. Trends Ecol Evol. 2006;21:451-7.

12. Hubbell $\mathrm{S}$. The unified neutral theory of biodiversity and biogeography. Princeton University Press: Princeton; 2001.

13. Schoener TW. The controversy over interspecific competition. Am Sci. 1982;70:586-95.

14. Abrams P. Some comments on measuring niche overlap. Ecology. 1980;61:44-9.

15. Codron D, Lee-Thorp JA, Sponheimer M, Codron J. Stable carbon isotope reconstruction of ungulate diet changes through the seasonal cycle. S Afr J Wildl Res. 2007;37:117-25.

16. Cerling TE, Harris JM, Passey BH. Diets of east African bovidae based on stable isotope analysis. J Mammal. 2003;84:456-70.

17. Codron D, Codron J, Lee-Thorp JA, Sponheimer M, de Ruiter D, Sealy J, et al. Diets of savanna ungulates from stable carbon isotope composition of faeces. J Zool. 2007;273:21-9.

18. Codron D, Codron J, Lee-Thorp JA, Sponheimer M, de Ruiter D. Animal diets in the Waterberg based on stable isotopic composition of faeces. S Afr J Wildl Res. 2005;35:43-52.

19. Salvarina I, Yohannes E, Siemers BM, Koselj K. Advantages of using fecal samples for stable isotope analysis in bats: evidence from a triple isotopic experiment. Rapid Commun Mass Spectrom. 2013;27:1945-53.

20. Cerling TE, Harris JM. Carbon isotope fractionation between diet and bioapatite in ungulate mammals and implications for ecological and paleoecological studies. Oecologia. 1999;120:347-63.

21. Codron $\mathrm{D}$, Codron J. Reliability of $\delta^{13} \mathrm{C}$ and $\delta^{15} \mathrm{~N}$ in faeces for reconstructing savanna herbivore diet. Mamm Biol Z Säugetierkd. 2009;74:36-48.
22. Tieszen LL, Hein D, Qvortrup SA, Troughton JH, Imbamba SK. Use of $\delta^{13} \mathrm{C}$ values to determine vegetation selectivity in East African herbivores. Oecologia. 1979:37:351-9.

23. Sponheimer M, Lee-Thorp JA, DeRuiter DJ, Smith JM, van der Merwe NJ, Reed K, et al. Diets of Southern African Bovidae: stable isotope evidence. J Mammal. 2003;84:471-9.

24. Leslie Jr DM, Bowyer RT, Jenks JA. Facts from feces : nitrogen still measures up as a nutritional index for mammalian herbivores. J Wild Manag. 2008; $72: 1420-33$.

25. Sealy JC, van der Merwe NJ, Thorp JAL, Lanham JL. Nitrogen isotopic ecology in southern Africa: Implications for environmental and dietary tracing. Geochim Cosmochim Acta. 1987;51:2707-17.

26. Kelly S, Heaton K, Hoogewerff J. Tracing the geographical origin of food: The application of multi-element and multi-isotope analysis. Trends Food Sci Technol. 2005;16:555-67.

27. Tanz N, Schmidt HL. $\delta^{34} \mathrm{~S}$-value measurements in food origin assignments and sulfur isotope fractionations in plants and animals. J Agric Food Chem. 2010;58:3139-46.

28. Bertolino S, Di Montezemolo NC, Bassano B. Food-niche relationships within a guild of alpine ungulates including an introduced species. J Zool. 2009;277:63-9.

29. Storms D, Aubry P, Hamann J-L, Saïd S, Fritz H, Saint-Andrieux C, et al. Seasonal variation in diet composition and similarity of sympatric red deer Cervus elaphus and roe deer Capreolus capreolus. Wildl Biol. 2008;14:237-50.

30. Schwartz CC, Ellis JE. Feeding ecology and niche separation in some native and domestic ungulates on the shortgrass prairie. J Appl Ecol. 1981;18:343-53.

31. Djagoun CAMS, Codron D, Sealy J, Mensah GA, Sinsin B. Stable carbon isotope analysis of the diets of West African bovids in Pendjari Biosphere Reserve, Northern Benin. S Afr J Wildl Res. 2013:43:33-43.

32. Hopcraft JG, Anderson TM, Pérez-Vila S, Mayemba E, Olff H. Body size and the division of niche space: food and predation differentially shape the distribution of Serengeti grazers. J Anim Ecol. 2012;81:201-13.

33. Wegge $P$, Shrestha AK, Moe SR. Dry season diets of sympatric ungulates in lowland Nepal: competition and facilitation in alluvial tall grasslands. Ecol Res. 2006;21:698-706.

34. Bagchi S, Goyal SP, Sankar K. Niche relationships of an ungulate assemblage in a dry tropical forest. J Mammal. 2003;84:981-8.

35. Dinerstein E. An ecological survey of the Royal Karnali-Bardia Wild life Reserve, Nepal: Part III: ungulate populations. Biol Conserv. 1980;18:5-37.

36. Karanth KU, Sunquist ME. Population structure, density and biomass of large herbivores in the tropical forests of Nagarahole. India J Trop Ecol. 1992:8:21-35.

37. Odden M, Wegge P. Predicting spacing behavior and mating systems of solitary cervids: a study of hog deer and Indian muntjac. Zoology. 2007;110:261-70.

38. Sharma K, Rahmani AR, Chundawat RS. Natural History Observations of the four-horned antelope Tetracerus quadricornis. J Bombay Nat Hist Soc. 2009;106:72-82.

39. Barrette C. Some aspects of the behaviour of muntjacs in Wilpattu National Park. Mammalia. 1977:41:1-34.

40. Hofmann RR. Evolutionary steps of ecophysiological adaptation and diversification of ruminants: a comparative view of their digestive system. Oecologia. 1989;78:443-57.

41. Yonzon PB. Ecological studies on Muntiacus muntjac (Zimmermann). J Nat Hist Mus. 1978;2:91-100.

42. Nagarkoti A, Thapa TB. Food habits of barking deer (Muntiacus muntjac) in the middle hills of Nepal. Hystrix Ital J Mamm. 2007:18:77-82.

43. Solanki GS, Naik RM. Grazing interactions between wild and domestic herbivores. Small Rumin Res. 1998:27:231-5.

44. Baskaran N, Kannan V, Thiyagesan K, Desai AA. Behavioural ecology of four-horned antelope (Tetracerus quadricornis de Blainville, 1816) in the tropical forests of southern India. Mamm Biol. 2011;76:741-7.

45. Farquhar G, O'Leary MH, Berry JA. On the relationship between carbon isotope discrimination and the intercellular carbon dioxide concentration in leaves. Funct Plant Biol. 1982;9:121-37.

46. Körner C, Farquhar GD, Roksandic Z. A global survey of carbon isotope discrimination in plants from high altitude. Oecologia. 1988;74:623-32.

47. Elmore CD, Paul RN. Composite list of $C_{4}$ weeds. Weed Sci. 1983;31:686-92.

48. Abideen Z, Ansari R, Gul B, Khan MA. The place of halophytes in Pakistan's biofuel industry. Biofuels. 2012;3:211-20. 
49. Zervoudakis G, Georgiou CD, Angelopoulos K. Pyruvate kinase activity in crude extracts of leaves of Cynodon dactylon and other $C_{4}$ plants. Russ J Plant Physl. 2001;48:171-5.

50. Su PX, Xie TT, Zhou ZJ. $C_{4}$ plant species and geographical distribution in relation to climate in the desert vegetation of China. Sci Cold Arid Reg. 2011:3:381-91.

51. Sale PF. Overlap in resource use, and interspecific competition. Oecologia. 1974;17:245-56.

52. Teng $L$, Liu Z, Song $Y-Y$, Zeng Z. Forage and bed sites characteristics of Indian muntjac (Muntiacus muntjak) in Hainan Island. China Ecol Res. 2004;19:675-81.

53. Timmins RJ, Duckworth JW, Pattanavibool A, Steinmetz R, Samba Kumar N, Anwarul Islam M, Baral HS: Muntiacus vaginalis. In IUCN Red List of Threatened Species. Version 2013.2. IUCN; 2008. <www.iucnredlist.org>. Downloaded on 12 Oct 2014

54. Krishna YC, Krishnaswamy J, Kumar NS. Habitat factors affecting site occupancy and relative abundance of four-horned antelope. J Zool. 2008;276:63-70.

55. Brodie JF, Brockelman WY. Bed site selection of red muntjac (Muntiacus muntjak) and sambar (Rusa unicolor) in a tropical seasonal forest. Ecol Res. 2009;24:1251-6.

56. Baskaran N, Desai AA, Udhayan A. Population distribution and conservation of the four-horned antelope (Tetracerus quadricornis) in the tropical forest of Southern India. J Sci Trans Environ Technol. 2009;2:139-44.

57. Pokharel KP, Ludwig T, Storch I. Spatial niche partitioning in sub-tropical solitary ungulates: four-horned antelope and barking deer in Nepal. PLoS One. 2015;10:e0117917.

58. Sparks DR, Malechek JC. Estimating percentage dry weight in diets using a microscopic technique. J Range Manag Arch. 1968;21:264-5.

59. Richards MP, Fuller BT, Sponheimer M, Robinson T, Ayliffe L. Sulphur isotopes in palaeodietary studies: a review and results from a controlled feeding experiment. Int J Osteoarchaeol. 2003;13:37-45.

60. Stable FB, Ecology I. Volume 82. New York: Springer; 2006

61. Cook GD. Effects of frequent fires and grazing on stable nitrogen isotope ratios of vegetation in northern Australia. Austral Ecol. 2001;26:630-6.

62. Grogan P, Bruns TD, Chapin III FS. Fire effects on ecosystem nitrogen cycling in a Californian bishop pine forest. Oecologia. 2000;122:537-44

63. Beghin R, Cherubini P, Battipaglia G, Siegwolf R, Saurer M, Bovio G. Tree-ring growth and stable isotopes $\left({ }^{13} \mathrm{C}\right.$ and $\left.{ }^{15} \mathrm{~N}\right)$ detect effects of wildfires on tree physiological processes in Pinus sylvestris L. Trees. 2011;25:627-36.

64. Arsenault $\mathrm{R}$, Owen-Smith N. Facilitation versus competition in grazing herbivore assemblages. Oikos. 2002;97:313-8.

65. Dinerstein E. An ecological survey of the royal Karnali-Bardia Wildlife Reserve, Nepal. Part I: Vegetation, modifying factors, and successional relationships. Biol Conserv. 1979;15:127-50

66. Lehmkuhl JF. The ecology of a south Asian tall grass community. University of Washington: Dissertation Abstracts International. B, Sciences and Engineering; 1990. p. 50-8.

67. Dunbar RIM. Competition and niche separation in a high altitude herbivore community in Ethiopia. Afr J Ecol. 1978;16:183-99.

68. Prins HHT, De Boer WF, Van Oeveren H, Correia A, Mafuca J, Olff H. Co-existence and niche segregation of three small bovid species in southern Mozambique. Afr J Ecol. 2006;44:186-98.

69. Shrestha KK, Jha PK, Ghimire JK. Final Technical Report: Plant Diversity Analysis and Evaluation of Conservation Measures in the Royal Bardia National Park, Nepal. Kathmandu, Nepal: WWF Nepal Program; 1997.

70. Zar JH. Biostatistical Analysis. 5th ed. Prentice Hall: Upper Saddle River, New Jersey; 2009.

\section{Submit your next manuscript to BioMed Central and take full advantage of:}

- Convenient online submission

- Thorough peer review

- No space constraints or color figure charges

- Immediate publication on acceptance

- Inclusion in PubMed, CAS, Scopus and Google Scholar

- Research which is freely available for redistribution 